\title{
Involvement of G6PDH in heat stress tolerance in the calli from Przewalskia tangutica and Nicotiana tabacum
}

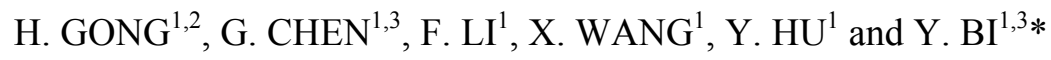 \\ School of Life Sciences, Lanzhou University, Lanzhou 730000, P.R. China ${ }^{1}$ \\ School of Life Science and Technology, Lanzhou University of Technology, Lanzhou 730000, P.R. China ${ }^{2}$ \\ Northwest Institute of Plateau Biology, Chinese Academy of Sciences, Xining 810008, P.R. China ${ }^{3}$
}

\begin{abstract}
Glucose-6-phosphate dehydrogenase (G6PDH) has been implicated in supplying reduced nicotine amide cofactors for biochemical reactions and in modulating the redox state of cells. In this study, the role of G6PDH in thermotolerance of the calli from Przewalskia tangutica and tobacco (Nicotiana tabacum L.) was investigated. Results showed that Przewalskia tangutica callus was more sensitive to heat stress than tobacco callus. The activity of G6PDH and antioxidant enzymes (ascorbate peroxidase, catalase, peroxidase and superoxide dismutase) in calli from Przewalskia tangutica and tobacco increased after $40^{\circ} \mathrm{C}$ treatment, although two calli exhibited a difference in the degree and timing of response to heat stress. When G6PDH was partially inhibited by glucosamine pretreatment, the antioxidant enzyme activities and thermotolerance in both calli significantly decreased. Simultaneously, the heat-induced $\mathrm{H}_{2} \mathrm{O}_{2}$ content and the plasma membrane NADPH oxidase activity were also reduced. Application of $\mathrm{H}_{2} \mathrm{O}_{2}$ increased the activity of G6PDH and antioxidant enzymes in both calli. Diphenylene iodonium, a NADPH oxidase inhibitor, counteracted heatinduced $\mathrm{H}_{2} \mathrm{O}_{2}$ accumulation and reduced the heat-induced activity of G6PDH and antioxidant enzymes. Moreover, exogenous $\mathrm{H}_{2} \mathrm{O}_{2}$ was effective in restoring the activity of G6PDH and antioxidant enzymes after glucosamine pretreatment. Western blot analysis showed that $G 6 P D H$ gene expression in both calli was also stimulated by heat and $\mathrm{H}_{2} \mathrm{O}_{2}$, and blocked by DPI and glucosamine under heat stress. Taken together, under heat stress G6PDH promoted $\mathrm{H}_{2} \mathrm{O}_{2}$ accumulation via NADPH oxidase and the elevated $\mathrm{H}_{2} \mathrm{O}_{2}$ was involved in regulating the activity of antioxidant enzymes, which in turn facilitate to maintain the steady-state $\mathrm{H}_{2} \mathrm{O}_{2}$ level and protect plants from the oxidative damage.
\end{abstract}

Additional key words: antioxidant enzymes, hydrogen peroxide, tobacco.

\section{Introduction}

Heat stress is expected to become a more frequent problem in the coming years (Wahid et al. 2007). Heat stress affects the structure of plants, especially cell membranes, and many basic physiological processes such as photosynthesis, respiration and water relations (Wahid et al. 2007). At the molecular level, the effect of heat stress reflects the temperature dependence of MichaelisMenten constant of every enzyme (Mitra and Bhatia
2008). To cope with heat stress, plants developed different mechanisms including the maintenance of cell membrane stability, regulation of oxidative stress by a synthesis of antioxidants, osmo-regulation, induction of some kinases or chaperones (Wahid et al. 2007).

Glucose-6-phosphate dehydrogenase (G6PDH, EC1.1.1.49) is the first and rate-limiting enzyme of the oxidative pentose phosphate pathway (OPPP). It controls

Received 7 January 2011, accepted 26 June 2011.

Abbreviations: APX - ascorbate peroxidase; CAT - catalase; DPI - diphenylene iodonium; EL - electrolyte leakage; G6PDH - glucose-6-phosphate dehydrogenase; GR - glutathione reductase; GSH - reduced glutathione; $\mathrm{H}_{2} \mathrm{O}_{2}$ - hydrogen peroxide; OPPP - oxidative pentose phosphate pathway; PM - plasma membrane; POD - peroxidase; ROS - reactive oxygen species; SOD - superoxide dismutase.

Acknowledgements: This work was supported by Chunhuijihua Z2008-1-62015, grants from visiting researcher foundation of Northwest Institute of Plateau Biology, Chinese Academy of Sciences, China, project of the National Eleventh-Five Year Research Program of China (2007BAC30B04), Specialized Research Fund for the Doctoral Program of Higher Education of China (20050730017).

* Corresponding author; fax: (+86) 931 8912561, e-mail: yrbi@1zu.edu.cn 
the carbon flow through OPPP and produces reducing equivalents in the form of NADPH to meet cellular needs for biochemical reactions and to modulate the redox state of cells (Kletzien et al. 1994, Krüger and Von Schaewen 2003). It has been indicated that G6PDH plays a protective role against oxidative stress (Kletzien et al. 1994, Pandolfi et al. 1995). G6PDH is also involved in nitrogen assimilation (Oji et al. 1985, Bowsher et al. 1989, Esposito et al. 2003), response to pathogenesis (Šindeláŕ and Šindelářová 2002, Scharte et al. 2009), metal toxicity (Esposito et al. 1998), salt stress (Nemoto and Sasakuma, 2000, Liu et al. 2007, Wang et al. 2008) and combination of drought and heat stress (Rizhsky et al. 2004). It was found that under salt stress G6PDH is involved in maintenance of intracellular reduced glutathione (GSH) in reed callus (Wang et al. 2008) or NADPH content in olive plants (Valderrama et al. 2006). These studies demonstrated that G6PDH might be a key enzyme in stress response. Recent results indicated that G6PDH contributes to the expression of pro-oxidative enzymes, including nitric oxide synthase and NADPH oxidase by supplying NADPH to plant cells (Pugin et al. 1997, Scharte et al. 2009).

Increase in ROS, such as superoxide anion and hydrogen peroxide, has been implicated in response to heat stress in plants (Königshofer et al. 2008). Numerous studies have shown that plasma membrane (PM) NADPH oxidase is the primary generator of ROS during biotic and abiotic stresses, including heat stress (Simon-Plas et al. 2002, Torres et al. 2002, Königshofer et al. 2008). The function of NADPH oxidase is to catalyze the extracellular formation of $\mathrm{O}_{2}{ }^{-}$from $\mathrm{O}_{2}$ using $\mathrm{NADPH}$ as an electron donor (Sagi and Fluhr 2001). Plants have evolved efficient enzymatic and non-enzymatic systems to counteract ROS, thereby protecting cells from oxidative damage and maintaining cellular homeostasis. Key enzymes include superoxide dismutases (SOD), catalases (CAT), peroxidases (POD), ascorbate peroxidases (APX) and other enzymes implicated in the ascorbate-glutathione pathway (Sairam et al. 2000, Chaitanya et al. 2002, Mishra et al. 2005, Locato et al. 2008). G6PDH has been recognized as an antioxidant enzyme, and is involved in protection against ROS under heat stress in yeast (Kim et al. 2006, Liao et al. 2009). However, the role of G6PDH in plants under heat stress was barely investigated.

Przewalskia tangutica, endemic to China, is mainly distributed in sandy and gritty land in dry grassland of the Qinghai-Tibet Plateau. It has been reported that it is of great medicinal importance (Yang, et al. 2002, Ren et al. 2008), but the physiological characteristics, especially the resistance to heat stress is unclear. In the present study, we used the calli from Przewalskia tangutica and tobacco (as a control) to investigate the physiological role of G6PDH in the tolerance to heat stress.

\section{Materials and methods}

Embryogenic callus, derived from leaves of Przewalskia tangutica Maxim (family Solanaceae), was obtained as described by Xu et al. (2008). The callus was subcultured on Murashige and Skoog (1962, MS) solid medium containing $0.5 \mathrm{mg} / \mathrm{dm}^{3} \alpha$-naphthaleneacetic acid (NAA), $0.5 \mathrm{mg} \mathrm{dm}^{-3}$ benzyladenine (6-BA) and $2.0 \mathrm{mg} \mathrm{dm}^{-3}$ 2,4-dichlorophenoxyacetic acid (2,4-D) at $25{ }^{\circ} \mathrm{C}$ in continuous darkness. Embryogenic callus from tobacco (Nicotiana tabacum L.) cv. Liuye was obtained as described by Tiburcio et al. (1985). The callus was subcultured on MS solid medium containing $0.5 \mathrm{mg} \mathrm{dm}^{-3}$ 6-BA and $2 \mathrm{mg} \mathrm{dm}^{-3}$ 2,4-D at $25{ }^{\circ} \mathrm{C}$ in the dark. Following 4-month sub-cultures, the calli from Przewalskia tangutica and tobacco were used for various treatments.

Heat stress was induced by incubation of calli at $40{ }^{\circ} \mathrm{C}$ for different times. To inhibit the G6PDH activity, $2 \mathrm{~cm}^{3}$ of $10 \mathrm{mM}$ glucosamine was added on the surface of the solid MS medium for $24 \mathrm{~h}$ after filter sterilization. During $5 \mathrm{~h}$ of $\mathrm{H}_{2} \mathrm{O}_{2}$ treatment, it was replaced by $2 \mathrm{~cm}^{3}$ of $1 \mathrm{mM} \mathrm{H} \mathrm{H}_{2} \mathrm{O}_{2}$ adding on the surface of the solid MS medium every $3 \mathrm{~h}$. To inhibit the ROS production, $2 \mathrm{~cm}^{3}$ of $25 \mu \mathrm{M}$ diphenylene iodonium (DPI) was added on the medium surface for $48 \mathrm{~h}$. Following the various treatments, heat stress was applied immediately and the calli were collected at indicated time points, washed for 2 min by distilled water, and excess water was blotted with filter paper. The samples were used immediately or stored at $-80^{\circ} \mathrm{C}$ for later use.

Electrolyte leakage (EL) was determined according to Sairam and Srivastava (2002) with some modifications. Calli $(0.1 \mathrm{~g})$ were collected and washed in de-ionized water for three times in order to remove surface-adhered electrolytes. Then, calli were placed in test tubes and immersed in $10 \mathrm{~cm}^{3}$ of de-ionized water for $3 \mathrm{~h}$ at $25^{\circ} \mathrm{C}$. After the incubation, the conductivity in the bathing solution was determined $\left(\mathrm{C}_{1}\right)$, and the conductivity of de-ionized water was also determined $\left(\mathrm{C}_{0}\right)$. The samples were heated in boiling water for $1 \mathrm{~h}$ before the total conductivity was measured in the bathing solution $\left(\mathrm{C}_{2}\right)$. Relative EL was expressed as a percentage of the total conductivity after heating in boiling water $\left[\mathrm{EL}=\left(\mathrm{C}_{1}-\mathrm{C}_{0}\right) /\left(\mathrm{C}_{2}-\mathrm{C}_{0}\right) \times 100\right]$.

$\mathrm{H}_{2} \mathrm{O}_{2}$ content was determined by the peroxidasecoupled assay according to Veljovic-Jovanovic et al. (2002). Callus was homogenized with $1 \mathrm{M} \mathrm{HClO}_{4}$ in the presence of $5 \%$ insoluble polyvinylpyrrolidone (PVP) at $4{ }^{\circ} \mathrm{C}$. The homogenate was centrifuged at $12000 \mathrm{~g}$ for $10 \mathrm{~min}$ at $4{ }^{\circ} \mathrm{C}$. The supernatant was neutralized with $5 \mathrm{M}$ $\mathrm{K}_{2} \mathrm{CO}_{3}$ to $\mathrm{pH} 5.6$ in $0.3 \mathrm{M}$ phosphate buffer ( $\mathrm{pH}$ 5.6). The 
resultant mixture was centrifuged at $12000 \mathrm{~g}$ at $4{ }^{\circ} \mathrm{C}$ for $1 \mathrm{~min}$ and the sample was incubated for $10 \mathrm{~min}$ with $1 \mathrm{U}$ ascorbate oxidase (Sigma, St. Louis, USA) to oxidize ascorbate prior to assay. The reaction mixture consisted of 0.1 M phosphate buffer ( $\mathrm{pH} 6.5$ ), $3.3 \mathrm{mM}$ 4-dimethylaminobenzoic acid (DMAB), $0.07 \mathrm{mM}$ 3-methyl-2benzothiazolinone hydrazone (MBTH), and 0.3 U POX. The reaction was initiated by adding $0.2 \mathrm{~cm}^{3}$ sample. The absorbance at $590 \mathrm{~nm}$ was monitored.

Callus $(0.5 \mathrm{~g})$ was ground with $3 \mathrm{~cm}^{3}$ ice-cold $50 \mathrm{mM}$ phosphate buffer ( $\mathrm{pH} 7.8$ ) containing $0.2 \mathrm{mM}$ EDTA and $1 \%$ PVP. The homogenates were centrifuged at $10000 \mathrm{~g}$ for $15 \mathrm{~min}$ at $4{ }^{\circ} \mathrm{C}$, and the supernatant was collected for enzyme assays. APX (EC 1.11.1.11) activity was measured according to Nakano and Asada (1981) by monitoring the rate of ascorbate oxidation at $290 \mathrm{~nm}$ (coefficient of absorbance, $\varepsilon=2.8 \mathrm{mM}^{-1} \mathrm{~cm}^{-1}$ ). CAT (EC 1.11.1.6) activity was measured as described by Durner and Klessing (1996) and calculated according to a decrease in absorbance at $240 \mathrm{~nm}\left(\varepsilon=39.4 \mathrm{mM}^{-1} \mathrm{~cm}^{-1}\right)$ following decomposition of $\mathrm{H}_{2} \mathrm{O}_{2}$. POD (EC 1.11.1.7) activity was measured according to Hammerschmidt et al. (1982) by monitoring the rate of guaiacol oxidation at $470 \mathrm{~nm}\left(\varepsilon=26.6 \mathrm{mM}^{-1} \mathrm{~cm}^{-1}\right)$. SOD (EC 1.15.1.1) activity was determined by the method of Beauchamp and Fridovich (1971). One unit of SOD was defined as the amount of enzyme required to cause $50 \%$ inhibition of the reduction of nitroblue tetrazolium as monitored at $560 \mathrm{~nm}$. All activity measurements were carried out at $25{ }^{\circ} \mathrm{C}$ in $3 \mathrm{~cm}^{3}$ reaction mixtures using a spectrophotometer DU640 (Beckman, USA) with no lag period.

G6PDH was extracted according to the method described by Esposito et al. (2001) with some modifications. Briefly, $0.5 \mathrm{~g}$ of callus was ground in liquid nitrogen and $1 \mathrm{~cm}^{3}$ of extraction buffer containing $50 \mathrm{mM}$ Hepes-Tris ( $\mathrm{pH} 7.8$ ), $3 \mathrm{mM} \mathrm{MgCl} 2,1 \mathrm{mM}$ EDTA, $1 \mathrm{mM}$ phenylmethylsulfonyl fluoride (PMSF), and $1 \mathrm{mM}$ dithiothreitol (DTT) was added. The homogenate was centrifuged at $12000 \mathrm{~g}$ for $20 \mathrm{~min}$ at $4{ }^{\circ} \mathrm{C}$. A $0.1 \mathrm{~cm}^{3}$ aliquot of supernatant was added to the total dehydrogenase (G6PDH + 6PGD) assay buffer [50 mM Hepes-Tris (pH 7.8), $3.3 \mathrm{mM} \mathrm{MgCl} 2,0.5 \mathrm{mM}$ D-glucose6-phosphate disodium salt, $0.5 \mathrm{mM}$ 6-phosphogluconate, $\left.0.5 \mathrm{mM} \mathrm{NADPNa}_{2}\right]$ and the 6-phosphogluconate dehydrogenase (6PGD) assay buffer [50 mM Hepes-Tris (pH 7.8), $3.3 \mathrm{mM} \mathrm{MgCl}_{2}, 0.5 \mathrm{mM}$ 6-phosphogluconate, $0.5 \mathrm{mM} \mathrm{NADPNa}_{2}$ ]. G6PDH activity was calculated as the difference of total dehydrogenase activity and the 6PGD activity (Tian et al. 1998).

\section{Results and discussion}

Several studies have provided evidence that cellular membranes are the primary sites of temperature perception (Königshofer et al. 2008, Saidi et al. 2009).
Plasma membranes were isolated by the method of Qiu and Su (1998) with some modifications. Callus $(10 \mathrm{~g})$ was homogenized in $20 \mathrm{~cm}^{3}$ isolation buffer containing $250 \mathrm{mM}$ sucrose, $25 \mathrm{mM}$ Hepes-Tris ( $\mathrm{pH} 7.6$ ), $1 \mathrm{mM}$ DTT, $1 \mathrm{mM}$ EDTA, $1.5 \%$ PVP, $1 \mathrm{mM}$ PMSF. The entire isolation procedure was carried out at $4{ }^{\circ} \mathrm{C}$. The homogenate was filtered through four layers of cheesecloth and centrifuged at $15000 \mathrm{~g}$ for $30 \mathrm{~min}$. The supernatant was centrifuged at $80000 \mathrm{~g}$ for $50 \mathrm{~min}$ to obtain a microsomal pellet (microsomal membranes), which was resuspended in a buffer containing $250 \mathrm{mM}$ sucrose, $1 \mathrm{mM}$ EDTA, $1 \mathrm{mM}$ DTT, and $2 \mathrm{mM}$ HepesTris ( $\mathrm{pH}$ 7.2). The microsomal membranes were used for the determination of NADPH oxidase activity.

NADPH oxidase activity assay was performed as described by Yang et al. (2003). The determination of the $\mathrm{NADPH}$-dependent $\mathrm{O}_{2}$-generation activity in isolated microsomal membranes was carried out by measuring the rate of SOD-inhibited reduction of NBT using NADPH as an electron donor. The reaction mixture consisted of $50 \mathrm{mM}$ Tris-HCl buffer ( $\mathrm{pH} 7.4), 250 \mathrm{mM}$ sucrose, $0.1 \mathrm{mM} \mathrm{NBT}, 0.02 \%(\mathrm{~m} / \mathrm{v})$ polyoxyethylenecetyl ether (Brij-58), and $0.03 \mathrm{~cm}^{3}$ isolated microsomal membranes (containing 50 - $100 \mu \mathrm{g}$ protein). After $1 \mathrm{~min}$ preincubation, the reaction was initiated by adding $0.1 \mathrm{mM}$ $\mathrm{NADPH}$, and the absorbance changes at $530 \mathrm{~nm}$ were recorded for $5 \mathrm{~min}$. Rates of $\mathrm{O}_{2}{ }^{--}$generation were calculated using $\varepsilon=12.8 \mathrm{mM}^{-1} \mathrm{~cm}^{-1}$. NBT reduction by $\mathrm{O}_{2}{ }^{-}$was determined from the difference of NBT reduction rates in the presence and absence of $50 \mathrm{U}$ SOD.

For Western blot analysis, SDS-PAGE was performed as described by Laemmli (1970). About $40 \mu \mathrm{g}$ proteins were solubilized and separated on an $11.5 \%(\mathrm{~m} / \mathrm{v})$ polyacrylamide gel containing $6 \mathrm{M}$ urea. After electrophoresis, the separated proteins were transferred to a polyvinylidene difluoride membrane. The membrane was blocked for 90 min with $5 \%$ non-fat milk in $0.5 \%(\mathrm{~m} / \mathrm{v})$ Tween 20, $10 \mathrm{mM}$ Tris- $\mathrm{HCl}$ ( $\mathrm{pH} 8.0)$, and $150 \mathrm{mM} \mathrm{NaCl}$. The polyclonal G6PDH antibody (Sigma) was added and incubated with the membrane overnight. After washing, alkaline phosphatase-coupled secondary antibody was added and incubated for $2 \mathrm{~h}$. The chemi-luminescence assays were performed according to the manufacturer's instruction. Protein concentration was determined by the Bradford (1976) method and bovine serum albumin was used as a standard.

Each experiment was repeated at least three times. All mean comparisons were done using Duncan's test for independent sample.

Cell membrane thermostability can be estimated through electrolyte leakage (EL) following exposure to heat stress (Heckman et al. 2002, Grigorova et al. 2011). Relative 
EL significantly increased after $2 \mathrm{~h}$ under $40{ }^{\circ} \mathrm{C}$ stress in Przewalskia tangutica callus, whereas it increased after $3 \mathrm{~h}$ in tobacco callus (Table 1). Heat stress caused a significant increase in $\mathrm{H}_{2} \mathrm{O}_{2}$ content in calli from both Przewalskia tangutica and tobacco. The $\mathrm{H}_{2} \mathrm{O}_{2}$ reached the highest content at $2 \mathrm{~h}$ of heat treatment in $P$. tangutica callus and at $3 \mathrm{~h}$ of heat treatment in tobacco callus. Longer exposure to heat stress resulted in no further increase in $\mathrm{H}_{2} \mathrm{O}_{2}$ contents in both calli (Table 1).

Heat stress induces oxidative stress, and several studies showed that G6PDH is involved in oxidative stress in plants (Zaka et al. 2002, Liu et al. 2007). The G6PDH activity in calli from $P$. tangutica and tobacco was induced by heat stress (Table 1). It reached the maximum in $P$. tangutica callus at $2 \mathrm{~h}$ of heat stress (123.4\% of the control), whereas in tobacco callus, it reached the maximum at $3 \mathrm{~h}$ of heat stress $(129.7 \%$ of the control).

Previous studies have elucidated that heat stress alters the activity of antioxidant enzymes including SOD, CAT, APX, and POD in many plant species such as potato, tomato, wheat and mulberry (Rainwater and Gossett 1996,

Table 1. Time course of changes in relative electrolyte leakage (EL), $\mathrm{H}_{2} \mathrm{O}_{2}$ content, and activities of G6PDH, APX, CAT, POD and $\mathrm{SOD}$ in calli from Przewalskia tangutica and tobacco under heat stress $\left(40{ }^{\circ} \mathrm{C}\right)$. Means of three replicates \pm SE. Different letters indicate statistically significant differences between treatments at the $5 \%$ level.

\begin{tabular}{|c|c|c|c|c|c|c|}
\hline \multirow[t]{2}{*}{ Parameter } & \multirow[t]{2}{*}{ Species } & \multicolumn{5}{|c|}{ Treatment time $[\mathrm{h}]$} \\
\hline & & 0 & 1 & 2 & 3 & 4 \\
\hline Relative EL & P. tangutica & $35.47 \pm 0.95 \mathrm{~d}$ & $36.37 \pm 1.49 \mathrm{~d}$ & $42.87 \pm 1.16 \mathrm{c}$ & $47.77 \pm 0.99 b$ & $54.97 \pm 0.90 \mathrm{a}$ \\
\hline$[\%]$ & tobacco & $40.87 \pm 1.31 \mathrm{c}$ & $41.80 \pm 0.96 \mathrm{c}$ & $43.33 \pm 1.57 \mathrm{c}$ & $46.80 \pm 1.31 \mathrm{~b}$ & $49.93 \pm 1.28 \mathrm{a}$ \\
\hline $\mathrm{H}_{2} \mathrm{O}_{2}$ content & P. tangutica & $1.91 \pm 0.08 b$ & $1.93 \pm 0.06 b$ & $2.67 \pm 0.12 \mathrm{a}$ & $1.84 \pm 0.11 \mathrm{~b}$ & $1.58 \pm 0.07 \mathrm{c}$ \\
\hline$\left[\mathrm{umol} \mathrm{mg} \mathrm{mg}^{-1}(\mathrm{~d} . \mathrm{m})\right]$ & tobacco & $1.78 \pm 0.06 \mathrm{c}$ & $1.80 \pm 0.12 \mathrm{c}$ & $2.16 \pm 0.09 b$ & $2.58 \pm 0.12 \mathrm{a}$ & $1.88 \pm 0.07 \mathrm{c}$ \\
\hline G6PDH activity & P. tangutica & $145.59 \pm 1.80 \mathrm{c}$ & $158.19 \pm 2.09 \mathrm{~b}$ & $179.68 \pm 2.99 \mathrm{a}$ & $162.96 \pm 3.11 \mathrm{~b}$ & $126.41 \pm 3.20 \mathrm{~d}$ \\
\hline$\left[\mu \mathrm{mol}(\mathrm{NADP}) \mathrm{mg}^{-1}\right.$ (prot.) $\left.\mathrm{min}^{-1}\right]$ & tobacco & $118.80 \pm 1.36 \mathrm{c}$ & $120.54 \pm 1.85 \mathrm{c}$ & $146.40 \pm 2.27 b$ & $154.12 \pm 2.07 \mathrm{a}$ & $145.30 \pm 1.77 b$ \\
\hline APX activity & P. tangutica & $4.12 \pm 0.15 \mathrm{c}$ & $4.52 \pm 0.18 \mathrm{~b}$ & $4.87 \pm 0.24 \mathrm{a}$ & $4.16 \pm 0.06 \mathrm{c}$ & $4.09 \pm 0.11 \mathrm{c}$ \\
\hline$\left[\mu \mathrm{mol}\right.$ (asc.) $\mathrm{mg}^{-1}$ (prot.) $\left.\mathrm{min}^{-1}\right]$ & tobacco & $3.94 \pm 0.10 \mathrm{~d}$ & $4.94 \pm 0.21 \mathrm{c}$ & $6.84 \pm 0.11 \mathrm{~b}$ & $7.78 \pm 0.15 \mathrm{a}$ & $6.67 \pm 0.19 b$ \\
\hline CAT activity & $P$.tangutica & $57.34 \pm 1.55 \mathrm{c}$ & $61.17 \pm 2.09 b c$ & $75.20 \pm 0.92 \mathrm{a}$ & $65.20 \pm 1.55 b$ & $58.27 \pm 2.05 \mathrm{c}$ \\
\hline$\left[\operatorname{nmol}\left(\mathrm{H}_{2} \mathrm{O}_{2}\right) \mathrm{mg}^{-1}\right.$ (prot.) $\left.\mathrm{min}^{-1}\right]$ & tobacco & $86.50 \pm 1.86 \mathrm{e}$ & $128.13 \pm 1.33 \mathrm{c}$ & $154.23 \pm 2.13 \mathrm{a}$ & $143.53 \pm 2.35 b$ & $101.43 \pm 1.72 \mathrm{~d}$ \\
\hline POD activity & P. tangutica & $0.57 \pm 0.04 \mathrm{c}$ & $0.63 \pm 0.08 b$ & $0.87 \pm 0.03 \mathrm{a}$ & $0.89 \pm 0.13 \mathrm{a}$ & $0.64 \pm 0.09 b$ \\
\hline [ $\mu \mathrm{mol}$ (gua.) $\mathrm{mg}^{-1}$ (prot.) $\left.\mathrm{min}^{-1}\right]$ & tobacco & $5.38 \pm 0.17 \mathrm{~d}$ & $6.42 \pm 0.16 \mathrm{c}$ & $8.52 \pm 0.10$ & $9.01 \pm 0.15 \mathrm{a}$ & $8.56 \pm 0.20 \mathrm{~b}$ \\
\hline SOD activity & P. tangutica & $16.27 \pm 0.73 \mathrm{~d}$ & $29.07 \pm 0.66 \mathrm{a}$ & $26.80 \pm 0.67 b$ & $19.63 \pm 0.66 \mathrm{c}$ & $13.43 \pm 0.52 \mathrm{e}$ \\
\hline [U mg ${ }^{-1}$ (prot.) $\left.\min ^{-1}\right]$ & tobacco & $22.03 \pm 0.93 \mathrm{~d}$ & $23.27 \pm 1.08 \mathrm{~d}$ & $41.73 \pm 1.02 \mathrm{~b}$ & $46.13 \pm 1.09 \mathrm{a}$ & $33.60 \pm 0.64 \mathrm{c}$ \\
\hline
\end{tabular}

Table 2. Effect of glucosamine (Glucm) on G6PDH activity, relative electrolyte leakage, relative growth rate and activity of APX, CAT, POD and SOD in calli from Przewalskia tangutica and tobacco. $2 \mathrm{~cm}^{3} 10 \mathrm{mM}$ of Glucm was added to the surface of the medium and after $24 \mathrm{~h}$, calli were subjected to heat treatment $\left(40^{\circ} \mathrm{C}\right.$ for $\left.2 \mathrm{~h}\right)$. After treatment, calli were collected for determination of enzymes activity and EL. Relative growth rate was determined after calli were recovered for $7 \mathrm{~d}$ under control conditions. Means of three replicates \pm SE. Different letters indicate statistically significant differences between treatments at the $5 \%$ level.

\begin{tabular}{|c|c|c|c|c|c|}
\hline Parameter & Species & $\begin{array}{l}\text { Treatments } \\
\text { control }\end{array}$ & heat & Glucm & heat+Glucm \\
\hline $\begin{array}{l}\text { G6PDH activity } \\
\text { [nmol(NADP) } \mathrm{mg}^{-1} \text { (prot) } \mathrm{min}^{-1} \text { ] }\end{array}$ & P. tangutica & $144.43 \pm 3.01 \mathrm{~b}$ & $177.65 \pm 2.01 \mathrm{a}$ & $123.99 \pm 3.04 \mathrm{c}$ & $149.33 \pm 3.12 b$ \\
\hline$\left[\right.$ nmol(NADP) mg (prot.) min $\left.{ }^{-}\right]$ & tobacco & $112.07 \pm 3.73 \mathrm{c}$ & $143.45 \pm 2.3 \mathrm{a}$ & $95.06 \pm 2.84 \mathrm{~d}$ & $122.16 \pm 2.73 b$ \\
\hline Relative EL & P. tangutica & $35.47 \pm 0.95 c$ & $42.87 \pm 1.16 b$ & $37.01 \pm 0.91 \mathrm{c}$ & $48.21 \pm 1.21 \mathrm{a}$ \\
\hline$[\%]$ & tobacco & $40.87 \pm 0.81 b$ & $43.33 \pm 0.73 b$ & $42.50 \pm 1.21 \mathrm{~b}$ & $47.01 \pm 1.21 \mathrm{a}$ \\
\hline Relative growth rate & P. tangutica & $100.00 \pm 2.66 \mathrm{a}$ & $86.73 \pm 2.18 b$ & $90.43 \pm 3.20 \mathrm{~b}$ & $76.54 \pm 2.79 \mathrm{c}$ \\
\hline$[\%]$ & tobacco & $100.00 \pm 3.95 \mathrm{a}$ & $98.47 \pm 3.09 \mathrm{a}$ & $92.54 \pm 2.92 b$ & $83.95 \pm 1.48 \mathrm{c}$ \\
\hline APX activity & P. tangutica & $4.08 \pm 0.17 \mathrm{~d}$ & $4.95 \pm 0.17 \mathrm{a}$ & $4.28 \pm 0.26 \mathrm{c}$ & $4.56 \pm 0.21 b$ \\
\hline$\left[\mu \mathrm{mol}\left(\right.\right.$ asc.) $\mathrm{mg}^{-1}$ (prot.) $\left.\mathrm{min}^{-1}\right]$ & tobacco & $3.82 \pm 0.23 \mathrm{~d}$ & $6.95 \pm 0.24 \mathrm{a}$ & $4.45 \pm 0.10 \mathrm{c}$ & $6.01 \pm 0.12 b$ \\
\hline CAT activity & $P$.tangutica & $57.49 \pm 2.21 \mathrm{c}$ & $78.87 \pm 2.43 \mathrm{a}$ & $48.53 \pm 1.32 d$ & $62.23 \pm 2.12 b$ \\
\hline$\left[\mathrm{nmol}\left(\mathrm{H}_{2} \mathrm{O}_{2}\right) \mathrm{mg}^{-1}\right.$ (prot.) $\left.\mathrm{min}^{-1}\right]$ & tobacco & $85.47 \pm 3.45 c$ & $152.66 \pm 2.11 \mathrm{a}$ & $60.00 \pm 1.88 \mathrm{~d}$ & $100.01 \pm 2.79 b$ \\
\hline POD activity & P. angutica & $0.57 \pm 0.05 \mathrm{c}$ & $0.87 \pm 0.33 \mathrm{a}$ & $0.54 \pm 0.04 \mathrm{c}$ & $0.67 \pm 0.03 b$ \\
\hline [ $\mu \mathrm{mol}$ (gua.) $\mathrm{mg}^{-1}$ (prot.) $\mathrm{min}^{-1}$ ] & tobacco & $5.29 \pm 0.35 \mathrm{c}$ & $8.58 \pm 0.35 \mathrm{a}$ & $3.46 \pm 0.40 \mathrm{~d}$ & $6.98 \pm 0.35 b$ \\
\hline SOD activity & P. tangutica & $16.20 \pm 1.12 \mathrm{c}$ & $26.14 \pm 0.79 a$ & $13.64 \pm 1.32 \mathrm{~d}$ & $22.11 \pm 1.23 b$ \\
\hline$\left[\mathrm{U} \mathrm{mg}{ }^{-1}\right.$ (prot.) $\left.\min ^{-1}\right]$ & tobacco & $22.89 \pm 1.23 \mathrm{c}$ & $41.28 \pm 0.91 \mathrm{a}$ & $17.25 \pm 1.43 \mathrm{~d}$ & $37.03 \pm 1.81 \mathrm{~b}$ \\
\hline
\end{tabular}


Sairam et al. 2000, Chaitanya et al. 2002, Vacca et al. 2004). In this study, the activity of APX, CAT, POD and SOD in calli from both $P$. tangutica and tobacco increased rapidly under heat stress. The activity of APX, CAT and POD in $P$. tangutica callus reached the maximum at $2 \mathrm{~h}$ of heat stress (increased by 18.4, 31.2 and $47.7 \%$, respectively), while the SOD activity reached the maximum at $1 \mathrm{~h}$ of heat stress (increased by $78.7 \%$ ). In tobacco callus, the activity of APX, POD and SOD reached the maximum at $3 \mathrm{~h}$ of heat stress. They were $197.5,167.5$ and $209.4 \%$ of the control, respectively. The CAT activity reached the maximum at $2 \mathrm{~h}$ of heat stress (Table 1).

To examine the injury of callus cells caused by heat stress, both $P$. tangutica and tobacco calli were treated at $40{ }^{\circ} \mathrm{C}$ for $1 \mathrm{~h}$ to $4 \mathrm{~h}$, and then transferred to the fresh solid medium for a week at $25{ }^{\circ} \mathrm{C}$ in dark. Results showed that the $P$. tangutica callus became brownish or dead after heat stress for $3 \mathrm{~h}$ or longer; the tobacco callus turned to slight brownish after heat stress for $4 \mathrm{~h}$. The tobacco callus could recover to normal if exposure to heat stress was less than $4 \mathrm{~h}$ (data not shown). Based on changes in relative $\mathrm{EL}, \mathrm{H}_{2} \mathrm{O}_{2}$ content, enzyme activity and recovery test, $2 \mathrm{~h}$ heat stress treatment was used in further experiments.

To elucidate the role of G6PDH in calli thermotolerance, the G6PDH activity was inhibited by glucosamine. Glucosamine 6-phosphate (N-Glc-6-P) is a well-known competitive inhibitor of G6PDH (Glaser and Brown 1955). Glucosamine can be taken up by plant cells and is rapidly phosphorylated to N-Glc-6-P (Pugin et al. 1997). The G6PDH activity in application of glucosamine decreased by 13.7 and $11.6 \%$ in $P$. tangutica and tobacco calli, respectively (Table 2). The G6PDH activity in glucosamine + heat treatment decreased by 14.2 and $15.2 \%$ in $P$. tangutica and tobacco callus, respectively, compared to that in heat stress alone.

The relative EL in glucosamine + heat treatment increased by 12.5 and $8.5 \%$ in P. tangutica and tobacco callus, respectively, in comparison with that in the heat treatment alone (Table 2), whereas it did not change under glucosamine treatment alone. The growth rate of $P$. tangutica and tobacco callus after glucosamine pretreatment decreased by 9.6 and $7.5 \%$, compared to that in control condition. However, the growth rate was reduced by 11.7 and $14.7 \%$ after heat + glucosamine treatment in $P$. tangutica and tobacco callus, respectively, compared to that under heat treatment alone. These data showed that inhibition of G6PDH reduced the thermotolerance of both calli.

In order to understand whether there was a relationship between G6PDH and antioxidant enzymes, the activity of antioxidant enzymes was determined when G6PDH was inhibited. Results showed that the activity of antioxidant enzymes under glucosamine + heat treatment markedly decreased compared to that under heat treatment alone in both calli, although not all antioxidant enzyme activity reduced in glucosamine treatment alone compared to that in control condition (Table 2).

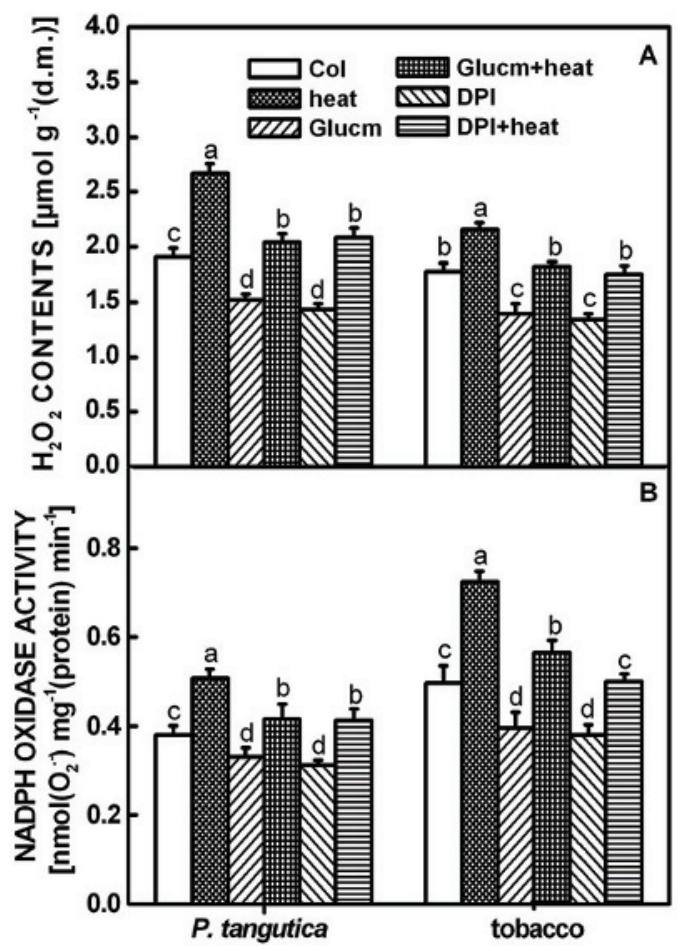

Fig. 1. Changes in $\mathrm{H}_{2} \mathrm{O}_{2}$ content $(A)$ and NADPH oxidase activity $(B)$ in calli from $P$. tangutica and tobacco. Calli were cultured on MS solid medium and $10 \mathrm{mM}$ Glucm or $25 \mu \mathrm{M}$ DPI were added to the surface of the medium for 24 or $48 \mathrm{~h}$, respectively. After that, calli were subjected to heat treatment $\left(40{ }^{\circ} \mathrm{C}, 2 \mathrm{~h}\right)$ and then $\mathrm{H}_{2} \mathrm{O}_{2}$ content and NADPH oxidase activity were measured (Col - control). Means \pm SE from three independent experiments. Different letters indicate statistically significant differences between treatments at the $5 \%$ level.

When the G6PDH activity was inhibited by glucosamine, the $\mathrm{H}_{2} \mathrm{O}_{2}$ content decreased by 20.3 and $21.8 \%$ in $P$. tangutica and tobacco callus, respectively (Fig. 1A). Under heat + glucosamine treatment, $\mathrm{H}_{2} \mathrm{O}_{2}$ contents in both calli from $P$. tangutica and tobacco decreased by 23.6 and $15.7 \%$, respectively, compared to that under heat stress alone. These results suggested G6PDH may play an important role in $\mathrm{H}_{2} \mathrm{O}_{2}$ accumulation under heat stress. Application of diphenylene iodonium (DPI), a potent inhibitor of PM NADPH oxidase, partially reduced the heat-induced $\mathrm{H}_{2} \mathrm{O}_{2}$ accumulation in both calli (Fig. $1 A$ ), suggesting that the NADPH oxidase is involved in $\mathrm{H}_{2} \mathrm{O}_{2}$ accumulation under heat stress, which was consistent with previous reports (Königshofer et al. 2008, Miller et al. 2009).

PM NADPH oxidase activity increased by 33.0 and $46.1 \%$ under heat stress in $P$. tangutica and tobacco callus, respectively, whereas it decreased significantly after glucosamine or DPI pretreatment (Fig. 1B). It also decreased significantly under glucosamine + heat or DPI 


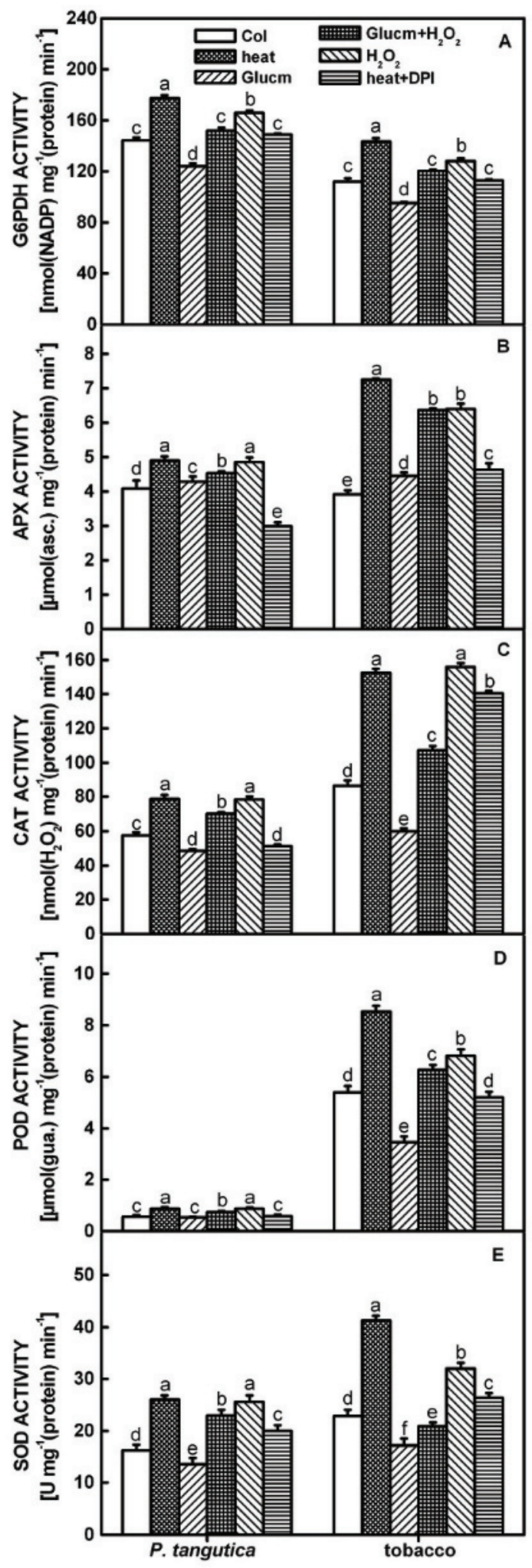

+ heat treatment compared to that under heat stress alone in both calli (Fig. 1B). These results demonstrated that G6PDH play a key role in the regulation of the NADPH
Fig. 2. Effects of $\mathrm{H}_{2} \mathrm{O}_{2}$ on the activities of G6PDH $(A)$, APX $(B)$, CAT $(C)$, POD $(D)$ and SOD $(E)$ in calli from Przewalskii tanguticae and tobacco. Calli were cultured on MS solid medium and $1 \mathrm{mM} \mathrm{H}_{2} \mathrm{O}_{2}$ was added to the surface for $5 \mathrm{~h}$. Calli were treated by DPI and Glucm and heat stress as in Fig. 1 (Col - control). Means \pm SE from three independent experiments. Different letters indicate statistically significant differences between treatments at the $5 \%$ level.

oxidase activity and the $\mathrm{H}_{2} \mathrm{O}_{2}$ accumulation in both calli under heat stress.

Effect of exogenous $\mathrm{H}_{2} \mathrm{O}_{2}$ on the activity of G6PDH and antioxidant enzymes was determined. The G6PDH activity was induced by $\mathrm{H}_{2} \mathrm{O}_{2}$ in both calli (Fig. 2). Similarly, the activity of four tested antioxidant enzymes also increased in the presence of $\mathrm{H}_{2} \mathrm{O}_{2}$. Pretreatment with DPI reduced the heat-induced G6PHD activity in both calli. The heat-induced antioxidant enzyme activity also markedly decreased after DPI pretreatment in both calli. Furthermore, $\mathrm{H}_{2} \mathrm{O}_{2}$ was effective in rescuing the activity of G6PDH and antioxidant enzymes in glucosaminetreated calli. These results suggested that $\mathrm{H}_{2} \mathrm{O}_{2}$ might act as a signalling molecule in regulating the activity of G6PDH and antioxidant enzymes under heat stress.

G6PDH has been shown to respond to various oxidative stresses and viral infection at the level of mRNA abundance or enzyme activity (Batz et al. 1998, Nemoto and Sasakuma 2000, Šindelář and Šindelářová 2002). To clarify whether the change of the G6PDH activity under heat stress results from elevated protein content or specific activity, Western-blot analysis was carried out. Results showed that the G6PDH protein content in both $P$. tangutica and tobacco callus increased under heat stress (Fig. 3). DPI and glucosamine significantly inhibited the heat-induced expression of $G 6 P D H$ in both calli although the inhibition degree was less in tobacco callus than that in $P$. tangutica callus. Application of $\mathrm{H}_{2} \mathrm{O}_{2}$ stimulated the $G 6 P D H$ expression and restored the decrease of $G 6 P D H$ expression after glucosamine treatment (Fig. 3). These results demonstrated that the change of G6PDH activity under heat stress and other treatments were consistent with its protein abundance.

Heat stress induces oxidative injury and alters the activity of antioxidant enzymes. Previous studies have elucidated the importance of maintaining a favorable antioxidative level in plant adaptation to heat stress (Rainwater et al. 1996, Sairam et al. 2000, Chaitanya et al. 2002, Vacca et al. 2004). The aim of the present study is to investigate the roles of G6PDH in mediating intracellular redox homeostasis in calli from $P$. tangutica and tobacco under heat stress.

It has been found that the endogenous cellular antioxidant capability was crucial in determining the ability of plants to cope with stress condition (Locato et al. 2009). In this study, except APX, the activity of other antioxidant enzymes were higher in tobacco callus 


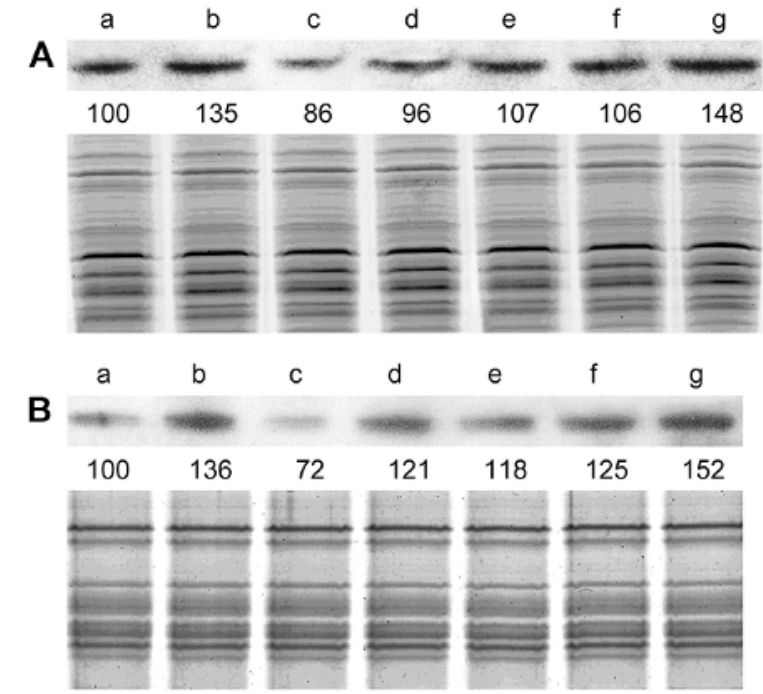

Fig. 3. Western-blot analysis of $G 6 P D H$ gene expression in calli from Przewalskia tangutica $(A)$ and tobacco $(B)$. In the experiment, $40{ }^{\circ} \mathrm{C}$ for $2 \mathrm{~h}, 1 \mathrm{mM} \mathrm{H}_{2} \mathrm{O}_{2}, 25 \mu \mathrm{M} \mathrm{DPI}$, and $10 \mathrm{mM}$ Glucm were used for different treatments. Lanes: a - control, b - heat, c - Glucm, d - Glucm + heat, e - DPI + heat, f - Glucm $+\mathrm{H}_{2} \mathrm{O}_{2}, \mathrm{~g}-\mathrm{H}_{2} \mathrm{O}_{2}$. Coomassie Brilliantt Blue-stained gel and the lane numbers show the relative amount of G6PDH protein in comparison with the control. Three independent experiments were performed.

than that in P. tangutica callus under both control as well as heat stress conditions. The change of relative EL is insignificant in tobacco callus in comparison to that in $P$. tangutica callus under heat stress (Table 1). Together with the injury experiment of heat stress in both calli (data not shown), our results showed that $P$. tangutica callus had lower thermotolerance than tobacco callus. These results also indicated that plant tolerance to heat stress is related to their habitat because tobacco originally grows in warm region whereas $P$. tangutica originally grows in cold region. The G6PDH activity and expression were also induced in both calli under heat stress (Table 1, Fig. 3). The relative EL significantly increased and the relative growth rate decreased in both calli after the heat-induced G6PDH activity and expression were inhibited by glucosamine (Table 2). This result demonstrated that G6PDH is involved in heat tolerance in both calli.

$\mathrm{H}_{2} \mathrm{O}_{2}$, primarily generated by PM NADPH oxidase, is rapidly accumulated upon high temperature and other stresses (Laloi et al. 2004, Königshofer et al. 2008). Our experiment demonstrated that the level of $\mathrm{H}_{2} \mathrm{O}_{2}$ significantly increased in both calli under heat stress (Table 1). Similarly, the endogenous $\mathrm{H}_{2} \mathrm{O}_{2}$ level in mustard seedlings subjected to heat stress increased by $65.0 \%$ in comparison with plants grown at $24{ }^{\circ} \mathrm{C}$ (Dat et al. 1998). In order to further identify the ROS-generating mechanism in both calli upon heat stress, we tested the effect of DPI, a potent inhibitor of PM NADPH oxidase.
Our results demonstrated that DPI inhibited the heatinduced NADPH oxidase activity and $\mathrm{H}_{2} \mathrm{O}_{2}$ production in both calli (Fig. 1), suggesting that NADPH oxidase is involved in heat-induced $\mathrm{H}_{2} \mathrm{O}_{2}$ production in both calli. Several reports have shown that immediate and sustained oxidative burst of NADPH oxidase relies on effective NADPH regeneration in the cytosol, and G6PDH is a key determinant for providing reducing equivalents to the NADPH oxidase (Pugin et al. 1997, Scharte et al. 2009). In this study, changes of the PM NADPH oxidase activity and $\mathrm{H}_{2} \mathrm{O}_{2}$ content followed a similar pattern with the G6PDH activity, which increased under heat stress and decreased by application of glucosamine (Fig. 1). These results suggested that G6PDH plays a key role in the accumulation of $\mathrm{H}_{2} \mathrm{O}_{2}$ by providing reducing equivalents to the NADPH oxidase.

$\mathrm{H}_{2} \mathrm{O}_{2}$ is considered as a central signalling molecule in plant responses to biotic and abiotic stresses (Foyer and Noctor 2005). It activates the protective mechanisms against high temperature in mustard seedlings (Dat et al. 1998), chilling in maize (Prasad et al. 1994), and photoinhibition in Arabidopsis leaves (Karpinski et al. 1999). Heat stress-induced $\mathrm{H}_{2} \mathrm{O}_{2}$ accumulation is required for effective expression of heat shock genes and APX genes (Volkov et al. 2006). Heat stress evoked $\mathrm{H}_{2} \mathrm{O}_{2}$ accumulation, stimulated the activity of antioxidant enzymes and G6PDH in both $P$. tangutica and tobacco calli (Table 1). Application of $\mathrm{H}_{2} \mathrm{O}_{2}$ induced the activity of antioxidant enzymes and G6PDH, and application of DPI decreased the heat-induced activity of the above enzymes (Fig. 2). It suggested that NADPH oxidasedriven $\mathrm{H}_{2} \mathrm{O}_{2}$ is involved in regulating the heat-induced activity of G6PDH and antioxidant enzymes. Furthermore, our results showed that glucosamine pretreatment not only inhibited the heat-induced G6PDH activity and $\mathrm{H}_{2} \mathrm{O}_{2}$ content (Figs. 1,2), but also reduced the antioxidant enzymes activities, increased the relative EL and decreased the relative growth rate in both calli (Fig. 2). Application of $\mathrm{H}_{2} \mathrm{O}_{2}$ was effective in restoring the activity of G6PDH and antioxidant enzymes after glucosamine pretreatment in both calli (Fig. 2). Taken together, G6PDH is involved in regulating heat-induced activation of antioxidant enzymes and heat tolerance by NADPH oxidase-driven ROS.

In conclusion, our data showed that G6PDH has a role in $\mathrm{H}_{2} \mathrm{O}_{2}$ production via NADPH oxidase under heat stress, thus is related to thermotolerance in $P$. tangutica and tobacco calli, although the two calli have different thermotolerance. Under heat stress, G6PDH and PM NADPH oxidase are induced, and then, the accumulation of $\mathrm{H}_{2} \mathrm{O}_{2}$ via $\mathrm{PM}$ NADPH oxidase stimulates the activity of G6PDH and antioxidant enzymes. The elevated G6PDH provides more NADPH for $\mathrm{H}_{2} \mathrm{O}_{2}$ generation. The enhanced antioxidant enzymes can scavenge $\mathrm{H}_{2} \mathrm{O}_{2}$, maintaining a steady-state level of $\mathrm{H}_{2} \mathrm{O}_{2}$ for cell signalling and thermotolerance. 


\section{References}

Antonio, F.T., Ravindar, K., Royal, B.I., Arthur, W.G.: Correlation between polyamines and pyrrolidine alkaloids in developing tobacco callus. - Plant Physiol. 78: 323-326, 1985.

Batz, O., Logemann, E., Reinold, S., Hahlbrock, K.: Extensive reprogramming of primary and secondary metabolism by fungal elicitor or infection in parsley cells. - Biol. Chem. 379: $1127-1135,1998$

Beauchamp, C., Fridovich, I.: Superoxide dismutase improved assays and an assay applicable to acrylamide gels. - Anal. Biochem. 44: 276-287, 1971.

Bowsher, C.G., Hucklesby, D.P., Emes, M.J.: Nitrite reduction and carbohydrate metabolism in plastids purified from roots of Pisum sativum L. - Planta 177: 359-366, 1989.

Bradford, M.M.: A rapid and sensitive method for the quantitation of microgram quantities of protein utilizing the principle of protein-dye binding. - Anal. Biochem. 72: 248254, 1976.

Chaitanya, K.V., Sundar, D., Masilamani, S., Ramachandra Reddy, A.R.: Variation in heat stress-induced antioxidant enzyme activities among three mulberry cultivars. - Plant Growth Regul. 36: 175-180, 2002.

Dat, J.F., Foyer, C.H., Scott, I.M.: Changes in salicylic acid and antioxidants during induced thermotolerance in mustard seedlings. - Plant Physiol. 118: 1455-1461, 1998.

Durner, J., Klessing, D.F.: Salicylic acid is a modulator of tobacco and mammalian catalases. - J. biol. Chem. 271: 28492-28502, 1996.

Esposito, S., Carfagna, S., Massaro, G., Vona, V., Di Martino Rigano, V.: Glucose-6-phosphate dehydrogenase in barley roots: kinetic properties and localization of the isoforms. Planta 212: 627-634, 2001.

Esposito, S., Carillo, E., Carfagna, S.: Ammonium metabolism stimulation of glucose-6-P dehydrogenase and phosphoenolpyruvate carboxylase in young barley roots. - J. Plant Physiol. 153: 61-66, 1998.

Esposito, S., Massaro, G., Vona, V., Di Martino Rigano, V., Carfagna, S.: Glutamate synthesis in barley roots: the role of the plastidic glucose-6-phosphate dehydrogenase. - Planta 216: 639-647, 2003.

Foyer, C.H., Noctor, G.: Redox homeostasis and antioxidant signaling: a metabolic interface between stress perception and physiological responses. - Plant Cell 17: 1866-1875, 2005.

Glaser, B.L., Brown, D.H.: Purification and properties of Dglucose 6-phosphate dehydrogenase. - J. biol. Chem. 216: $67-79,1955$.

Grigorova, B., Vaseva, I., Demirevska, K., Feller, U.: Combined drought and heat stress in wheat: changes in some heat shock proteins. - Biol. Plant. 55: 105-111, 2011.

Hammerschmidt, R., Nuckles, E.M., Kuc, J.: Association of enhanced peroxidase activity with induced systemic resistance of cucumber to Colletotrichum lagenarium. Physiol. Plant Pathol. 20: 73-82, 1982.

Heckman, N.L., Horst, G.L., Gaussoin, R.E., Tavener B.T.: Trinexapac-ethyl influence on cell membrane thermostability of Kentucky bluegrass leaf tissue. - Sci. Hort. 92: 183-186, 2002.

Karpinski, S., Reynolds, H., Karpinska, B., Wingsle, G., Creissen, G., Mullineaux, P.: Systemic signaling and acclimation in response to excess excitation energy in
Arabidopsis. - Science 284: 654-657, 1999.

Kim, I.S., Moon, H.Y., Yun, H.S., Jin, I.: Heat shock causes oxidative stress and induces a variety of cell rescue proteins in Saccharomyces cerevisiae KNU5377. - J. Microbiol. 44: 492-501, 2006.

Kletzien, R.F., Harris, P.K., Foellmi, L.A.: Glucose-6phosphate dehydrogenase: a "housekeeping" enzyme subject to tissue-specific regulation by hormones, nutrients, and oxidant stress. - FASEB J. 8: 174-181, 1994.

Königshofer, H., Tromballa, H.W., Löppert, H.G.: Early events in signalling high-temperature stress in tobacco BY2 cells involve alterations in membrane fluidity and enhanced hydrogen peroxide production. - Plant Cell Environ. 31: 1771-1780, 2008.

Krüger, N.J., Von Schaewen, A.: The oxidative pentose phosphate pathway: structure and organization. - Curr. Opin. Plant Biol. 6: 236-246, 2003.

Laemmli, U.K.: Cleavage of structural proteins during the assembly of the head of bacteriophage T4. - Nature 227: 680-685, 1970.

Laloi, C., Apel, K., Danon, A.: Reactive oxygen signalling: the latest news. - Curr. Opin. Plant Biol. 7: 23-328, 2004.

Liao, Y., Wei, Z.H., Bai, L., Deng, Z., Zhong, J.J.: Effect of fermentation temperature on validamycin A production by Streptomyces hygroscopicus 5008. - J. Biotechnol. 142: 271-274, 2009.

Liu, Y.G., Wu, R.R., Wan, Q., Xie, G.Q., Bi, Y.R.: Glucose-6phosphate dehydrogenase plays a pivotal role in nitric oxide-involved defense against oxidative stress under salt stress in red kidney bean roots. - Plant Cell Physiol. 48: 511-522, 2007.

Locato, V., De Pinto, M.C., De Gara, L.: Different involvement of the mitochondrial, plastidial and cytosolic ascorbateglutathione redox enzymes in heat shock responses. Physiol. Plant. 135: 296-306, 2009.

Locato, V., Gadaleta, C., De Gara, L., De Pinto, M.C.: Production of reactive species and modulation of antioxidant network in response to heat shock: a critical balance for cell fate. - Plant Cell Environ. 31: 1606-1619, 2008.

Miller, G., Schlauch, K., Tam, R., Cortes, D., Torres, M.A., Shulaev, V., Dangl, J.L., Mittler, R.: The plant NADPH oxidase RBOHD mediates rapid systemic signaling in response to diverse stimuli. - Sci. Signal. 2: 1-10, 2009.

Mishra, Y., Bhargava, P., Chand Rai, L.C.: Differential induction of enzymes and antioxidants of the antioxidative defense system in Anabaena doliolum exposed to heat stress. - J. Therm. Biol. 30: 524-531, 2005.

Mitra, R., Bhatia, C.R.: Bioenergetic cost of heat tolerance in wheat crop. - Curr. Sci. 94: 1049-1053, 2008.

Murashige, T., Skoog, F.: A revised medium for rapid growth and bioassay with tobacco tissue cultures. - Physiol. Plant 15: 473-497, 1962.

Nakano, Y., Asada, K.: Hydrogen peroxide is scavenged by ascorbate-specific peroxidase in spinach chloroplasts. Plant Cell Physiol. 22: 867-880, 1981.

Nemoto, Y., Sasakuma, T.: Specific expression of glucose-6phosphate dehydrogenase (G6PDH) gene by salt stress in wheat (Triticum aestivum L.). - Plant Sci. 158: 53-60, 2000.

Oji, Y., Watanabe, M., Wakiuchi, N., Okamoto, S.: Nitrite reduction in barley-root plastids: dependence on NADPH 
coupled with glucose-6-phoshate and 6-phosphogluconate dehydrogenases, and possible involvement of an electron carrier and a diaphorase. - Planta 165: 85-90, 1985.

Pandolfi, P.P., Sonati, F., Rivi, R., Mason, P., Grosveld, F., Luzzatto, L.: Targeted disruption of the housekeeping gene encoding glucose 6-phosphate dehydrogenase (G6PD): G6PD is dispensable for pentose synthesis but essential for defense against oxidative stress. - EMBO J. 14: 5209-5215, 1995.

Prasad, T.K., Anderson, M.D., Martin, B.A., Stewart, C.R.: Evidence for chilling-induced oxidative stress in maize seedlings and a regulatory role for hydrogen peroxide. Plant Cell 6: 65-74, 1994.

Pugin, A., Frachisse, J.M., Tavernier, E., Bligny, R., Gout, E., Douce, R., Guern, J.: Early events induced by the elicitor cryptogein in tobacco cells: involvement of a plasma membrane NADPH oxidase and activation of glycolysis and the pentose phosphate pathway. - Plant Cell 9: 2077-2091, 1997.

Qiu, Q.S., Su, X.F. The influence of extracellular-side $\mathrm{Ca}^{2+}$ on the activity of the plasma membrane $\mathrm{H}^{+}$-ATPase from wheat roots. - Aust. J. Plant Physiol. 25: 923-928, 1998.

Rainwater, D.T., Gossett, D.R., Millhollon, E.P., Hanna, H.Y., Banks, S.W., Lucas, M.C.: The relationship between yield and the antioxidant defence system in tomatoes grown under heat stress. - Free Radical Res. 25: 421-435, 1996.

Ren, X.N., Ma, Y.J., Zhou, M., Huo, S.H., Yao, J.L., Chen, H.: Determination of tropane alkaloid components in Przewalskia tangutica Maxim. by capillary electrophoresis with electrochemiluminescence detection. - Chin. J. Chromatogr. 26: 223-227, 2008.

Rizhsky, L., Liang, H., Shuman, J., Shulaev, V., Davletova, S. Mittler, R.: When defense pathways collide. The response of Arabidopsis to a combination of drought and heat stress. Plant Physiol. 134: 1683-1696, 2004.

Sagi, M., Fluhr, R.: Superoxide production by plant homologues of the gp91 ${ }^{\text {phox }}$ NADPH oxidase. Modulation of activity by calcium and by tobacco mosaic virus infection. - Plant Physiol. 126: 1281-1290, 2001.

Saidi, Y., Finka, A., Muriset, M., Bromberg, Z., Weiss, Y.G., Maathuis, F.J.M., Goloubinoff, P.: The heat shock response in moss plants is regulated by specific calcium-permeable channels in the plasma membrane. - Plant Cell 21: 28292843, 2009.

Sairam, R.K., Srivastava, G.C.: Changes in antioxidant activity in subcellular fraction of tolerant and susceptible wheat genotypes in response to long term salt stress. - Plant Sci. 162: 897-904, 2002.

Sairam, R.K., Srivastava, G.C., Saxena, D.C.: Increased antioxidant activity under elevated temperature: a mechanism of heat stress tolerance in wheat genotypes. Biol. Plant. 43: 245-251, 2000.

Scharte, J., Schön, H., Tjaden, Z., Weis, E., Von Schaewen, A.: Isoenzyme replacement of glucose-6-phosphate dehydrogenase in the cytosol improves stress tolerance in plants. - Proc. nat. Acad. Sci. USA 106: 8061-8066, 2009.

Simon-Plas, F., Elmayan, T., Blein, J.P.: The plasma membrane oxidase NtrbohD is responsible for AOS production in elicited tobacco cells. - Plant J. 31: 137-147, 2002.

Šindelář, L., Šindeláŕová, M.: Correlation of viral RNA biosynthesis with glucose-6-phosphate dehydrogenase activity and host resistance. - Planta 215: 862-869, 2002.

Tian, W.N., Braunstein, L.D., Pang, J., Stuhlmeier, K.M., Xi, Q.C., Tian, X., Stanton, R.C.: Importance of glucose-6phosphate dehydrogenase activity for cell growth. - J. biol Chem. 273: 10609-10617, 1998.

Tiburcio, A.F., Kaur-Sawhney, R., Ingersoll, R.B., Galston, A.W.: Correlation between polyamines and pyrrolidine alkaloids in developing tobacco callus. - Plant Physiol. 78: 323-326, 1985.

Torres, M.A., Dangl, J.L., Jones, J.D.G.: Arabidopsis gp91 ${ }^{\text {phox }}$ homologues AtrbohD and AtrbohF are required for accumulation of reactive oxygen intermediates in the plant defense response. - Proc. nat. Acad. Sci. USA 99: 517-522, 2002.

Vacca, R.A., De-Pinto, M.C., Valenti, D., Passarella, S., Marra, E., De-Gara, L.: Production of reactive oxygen species, alteration of cytosolic ascorbate peroxidase, and impairment of mitochondrial metabolism are early events in heat shockinduced programmed cell death in tobacco bright-yellow 2 cells. - Plant Physiol. 134: 1100-1112, 2004.

Valderrama, R., Corpas, F.J., Carreras, A., Gómez-Rodríguez, M.V., Chaki, M., Pedrajas, J.R., Fernández-Ocaña, A., DelRío, L.A., Barroso, J.B.: The dehydrogenase-mediated recycling of NADPH is a key antioxidant system against salt-induced oxidative stress in olive plants. - Plant Cell Environ. 29: 1449-1459, 2006.

Veljovic-Jovanovic, S.D., Noctor, G., Foyer, C.H.: Are leaf hydrogen peroxide concentrations commonly overestimated? The potential influence of artefactual interference by tissue phenolics and ascorbate. - Plant Physiol. Biochem. 40: 501-507, 2002.

Volkov, R.A., Panchuk I.I., Mullineaux P.M., Schöffl F.: Heat stress-induced $\mathrm{H}_{2} \mathrm{O}_{2}$ is required for effective expression of heat shock genes in Arabidopsis. - Plant mol. Biol. 61: 733746, 2006.

Wahid, A., Gelani, S., Ashraf, M., Foolad, M.R.: Heat tolerance in plants: an overview. - Environ. exp. Bot. 61: 199-223, 2007.

Wang, X.M., Ma, Y.Y., Huang, C.H., Li, J.S., Wan, Q., Bi, Y.R.: Glucose-6-phosphate dehydrogenase plays a central role in modulating reduced glutathione levels in reed callus under salt stress. - Planta 227: 611-623, 2008.

Xu, W.H., Chen, G.C., Zhou, G.Y., Sun, J., Lu, X.F.: Rapid propagation in a Tibetan medicine plant - Przewalskia tangutica. - Chin. Traditional Herbs Drugs 40: 297-300, 2008.

Yang, D.Z., Zhang, Z.Y., Lu, A.M., Sun, K., Liu, J.Q.: Floral organogenesis and development of two taxa in tribe Hyoscyameae (Solanaceae) - Przewalskia tangutica and Hyoscyamus niger. - Acta bot. sin. 44: 889-894, 2002.

Yang, Y.L., Zhang, F., He, W.L., Wang, X.M., Zhang, L.X.: Iron-mediated inhibition of $\mathrm{H}^{+}$-ATPase in plasma membrane vesicles isolated from wheat roots. - Cell Mol. Life Sci. 60: 1249-1257, 2003.

Zaka, R., Vandecasteele, C.M., Misset, M.T.: Effects of low chronic doses of ionizing radiation on antioxidant enzymes and G6PDH activities in Stipa capillata (Poaceae). - J. exp. Bot. 53: 1979-1987, 2002. 